\title{
CORRIGENDUM
}

\section{Toxic absorption of pimecrolimus in a patient with severe acute graft-versus-host disease}

DL Neuman, JE Farrar, JM Moresi, GB Vogelsang and MA Higman

Bone Marrow Transplantation (2006) 38, 81. doi:10.1038/sj.bmt.1705234

Correction to: Bone Marrow Transplantation (2005) 36, 919-920. doi:10.1038/sj.bmt1705146

My attention has been drawn to the fact that the authors of this letter believed that the patient's cutaneous GvHD was treated with pimecrolimus (Elidel cream), whereas the pharmacy used their approved formulary and dispensed tacrolimus ointment. Thus, tacrolimus (and not pimecrolimus) was presumably absorbed through the skin and this would have explained the high serum levels of tacrolimus referred to in the letter. The patient never received pimecrolimus. The title of the published letter should therefore have been 'Toxic absorption of tacrolimus in a patient with severe acute graft-versus-host disease.'

The authors regret this error.

JM Goldman Editor 